\title{
RELIGION AND MENTAL HEALTH: ASPECTS OF THE RELATION BETWEEN RELIGIOUS MEASURES AND POSITIVE AND NEGATIVE MENTAL HEALTH
}

\author{
Femke Janssen, Sarah Bänziger, \\ Jessie Dezutter and Dirk Hutsebaut*
}

\begin{abstract}
Studies concerning the relationship between religion and mental health have provided substantial evidence for the existence of a positive relationship. Nevertheless, it remains largely unclear which aspects of both religion and mental health take part in this relationship. The present study uses multiple measures of religion and of mental health to obtain a more refined view of this relationship. The results show the importance of distinguishing between if a person believes (inclusion vs. exclusion of transcendence) and how a person believes (literal vs. symbolic). Religious persons who have a symbolic attitude towards religion scored higher on positive aspects of mental health (well-being). No significant results were found for negative mental health (psychological distress).
\end{abstract}

Studies concerning the relationship between religion and mental health have gathered mounting evidence for an overall positive relationship. In a recent meta-analysis of 34 studies, Hackney and Sanders (2003) concluded that religion and mental health go together. However, it remains unclear which aspects of religion and mental health provoke this relation, which has also been pointed out by several other scholars (e.g., Ellison, Boardman, Williams, \& Jackson, 2001). This issue seems to be a returning problem within this field of research.

* Femke Janssen. Department of Cultural and Personality Psychology, Radboud University, PO Box 9104, 6500 HE Nijmegen, The Netherlands.

Sarah Bänziger. Department of Cultural and Personality Psychology, Radboud University, PO Box 9104, 6500 HE Nijmegen, The Netherlands. E-mail: s.bänziger@, psych.ru.nl

Jessie Dezutter. K.U. Leuven, Department of Psychology, Tiensestraat 102, B-3000 Leuven, Belgium. E-mail: Jessie.Dezutter@psy.kuleuven.ac.be.

Dirk Hutsebaut. K.U. Leuven, Department of Psychology, Tiensestraat 102, B-3000 Leuven, Belgium. E-mail: Dirk.Hutsebaut@psy.kuleuven.ac.be.

Correspondence concerning this article should be addressed to: Sarah Bänziger E-mail: s.bänziger@psych.ru.nl 
The aim of the present study is to explore which aspects of religion and of mental health are of importance within this relation. This should lead to a better insight in the complicated religion-mental health relationship. Below, we will first discuss often-used religious measures and their pros and cons. Then we will go into various aspects of mental health and discuss previous findings on the relation of these aspects with religion. Finally, we will formulate our hypotheses regarding the influence of religion on mental health.

\section{Religion}

The concept of religion can be approached in many ways. Likewise, psychologists have developed different ways of measuring religion. Often used are single-items (e.g., church attendance, belief salience), popular for fast use and easy interpretation. However, these advantages also bring disadvantages. Because of their unidimensionality, single-items do not always give a broad view of religion. For example, church attendance is unlikely to give a good representation of a person's religiosity. In the Netherlands, $60 \%$ of the population stated that they belong to a religious affiliation, while only $29 \%$ visits a church at least once a month (CBS, 2002). So, church attendance does not overlap sufficiently with religiosity to qualify as a good measure of religion. In this respect, belief salience offers a better representation of a person's religiosity. Still, it fails to cover different sides of religion due to its unidimensionality. Although it gives a good measure of "intrinsic pro-religiousness", it does not adequately measure orthodoxy (Gorsuch \& MacFarland, 1972). When interested in the underlying relationships between religion and mental health this measure is not satisfying.

One of the most used multiple-item scales for measuring religion is the Religious Orientation Scale (ROS; Allport \& Ross, 1967). This scale is designed to reveal a person's religious motivation. A distinction is made between intrinsic and extrinsic religious motivation. Persons with an intrinsic orientation are described by Allport and Ross (1967) as "[those who] find their master motive in religion" and "[someone who] lives his religion", whereas persons with an extrinsic religious motivation "use religion for their own ends" to provide "security and solace, sociability and distraction, status and self-justification" (p. 434). Although this scale has had a large impact on religion and 
mental health research, it has also been strongly criticized (Hunt \& King, 1971; Kirkpatrick \& Hood, 1990). First, the underlying dimensions of the ROS are unclear. Allport originally assumed intrinsic and extrinsic religiousness to fall upon one bipolar factor, considering them as opposites. However, Feargin (1964) found that the underlying structure contained two unipolar dimensions, upon which Allport and Ross concluded that intrinsic and extrinsic are orthogonally related. Although the orthogonal relation was quickly adopted, the change in dimensionality created ambiguity on how intrinsicness and extrinsicness are conceptually interrelated (Kirkpatrick \& Hood, 1990). This brings us to a second point of criticism: the content of the intrinsic-extrinsic concepts. As concluded in a research by Donahau (1985), intrinsic religiousness is a good measure of religious commitment. It correlates with diverse measures of religiosity. Extrinsic religiousness does not correlate with any religious measures. If extrinsic religiousness does not measure religious motivation, the question is what it does measure (Kirkpatrick \& Hood, 1990). Thus, as intrinsic religiousness relates to religion and extrinsic religiousness does not, this scale does not appear to measure different ways of being religious.

In spite of the criticism, the intrinsic-extrinsic distinction is still one of today's most frequently used in research of religion. This is partly the consequence of the few good alternatives available. However, a rather recent theoretical model developed by Wulff (1991) has evolved to a potential alternative. Wulff introduced a model that grasps four different religious attitudes located in a two-dimensional space along two bipolar axes. The vertical axis specifies the degree to which objects of religious interest are granted in a transcendent reality, and the horizontal axis specifies whether religion is interpreted in a literal or symbolic way. The four religious attitudes in this model are literal affirmation in the upper left quadrant, literal disaffirmation in the lower left quadrant, restorative interpretation in upper right quadrant, and reductive interpretation in the lower right quadrant. Building on this theoretical framework and the terminology of Ricoeur (see Ricoeur, 1970), the Post-Critical Belief Scale was developed (PCBS; Duriez, Fontaine \& Hutsebaut, 2000). This scale measures the degree to which a person belongs to the four religious attitudes orthodoxy (literal affirmation), external critique (literal disaffirmation), second naiveté (restorative interpretation), and relativism (reductive interpretation). An important advance of the PCBS is the distinction in if a person is religious (inclusion vs. exclusion of transcendence) 
and how a person is religious (literal vs. symbolic). This characteristic is not present in the scales that are discussed above. The singleitems only measure whether a person is religious and the ROS only attempts to measure how a person is religious. None of the scales measure both. Therefore, in this article, we emphasize the PCBS. We think that this scale can show the most complete view of the complicated relationship between religion and mental health.

\section{Mental Health}

An important problem in the research of religion and mental health is the broad variety of operationalizations of mental health, which makes it difficult to compare results. Some researchers have emphasized the importance of a distinction between positive mental health, usually designated as well-being, and negative mental health, usually designated as psychological distress (Ellison, 1991). This refinement seems to be important since researchers usually find a positive relationship between religion and positive mental health, whereas the relationship between religion and negative mental health is rather ambiguous (see e.g., Ellison, Broardman, Williams, \& Jackson, 2001).

A more refined distinction comes from Batson, Schoenrade, and Ventis (1992). They reviewed over a hundred studies and divided them into different categories of mental health. With this review as a starting point, we included the following aspects of mental health (the categories of Batson, Schoenrade, and Ventis placed in parenthesis): depression and anxiety (absence of mental illness), appropriate social behavior, self-esteem and self-actualisation (self-acceptance or self-actualisation), purpose in life (personal unification and organisation), and openness to experience (open-mindedness and flexibility). Another aspect of mental health is subjective well-being, which was not discussed by Schoenrade, Batson, and Ventis because of its recent appearance within this area of research. However, because of the great attention it receives we added it to our list. Below, we discuss these different aspects of mental health in more detail.

\section{Depression and Anxiety}

When mental health is operationalized in a more clinical way, depression and anxiety are one of the most often used measures. In his review, Gartner (1996) claims that depression and religion are mainly negatively related. More recent studies confirm this relationship (Blaine, 
Trivedi, \& Eshleman, 1998; Braam, Beekman, Deeg, \& van Tilburg, 1994; Braam, Beekman, Smit \&, van Tilburg, 1997; Maltby \& Day, 2000; Maltby, Lewis, \& Day, 1999). Earlier research with the PCBS, however, showed a positive relation between orthodoxy and depression (Luyten, Corveleyn, \& Fontaine; 1998). The same results emerged for external critique. Both are literal attitudes towards religion. Thus, how a person is religious also seems to be an important factor in the relationship between religion and depression.

Scholars reviewing the relationship between religion and anxiety claim that this relationship is ambiguous (Koenig, 1994; Gartner, 1996). Whereas some studies find a negative relationship (Bergin, Masters, \& Richards, 1987; Maltby \& Day, 2000; Maltby, Lewis, \& Day, 1999), others find no relationship (Frenz \& Carey, 1989; Watson, Morris, \& Hood, 1988). Results in the study of Luyten, Corveleyn, and Fontaine (1998) also showed no relationships between the four religious attitudes of the PCBS and anxiety. So far, it remains unclear whether anxiety plays a part in the relationship between religion and mental health.

\section{Appropriate Social Behavior}

In North-American and European studies there seems to be agreement about the operationalization of appropriate social behavior. Measures of drug use, alcohol use and premarital sexual behavior are frequently used. Research shows a negative relation of drug and alcohol use with religion (Dudley, Mutch, \& Cruise, 1987; Engs \& Mullen, 1999; Hadaway, Elifson, \& Petersen. 1984) and of premarital sexual behavior with religion (Beck, Cole, \& Hammond, 1991; Cochran \& Beeghley, 1991; Hearich, 1992). These results are confirmed in reviews by Gartner (1996) and Hood, Spilka, Hunsberger, and Gorsuch (1996), where they state that most studies find a negative relationship. Another aspect of appropriate social behavior used in this research area is cheating. Here, the results are also pointing in the direction of a negative relationship (Grasmick, Kinsey, \& Cochran, 1991; Welch, Tittle, \& Petee, 1991).

These results are not surprising, because it is a well-known fact that most religions emphasize the importance of moral and social behavior. Religion can be a source of norms and values for the individual and can therefore have a large influence on a person's behavior. The more a person is guided by his or her religion, the more he or she will live in conformity with the preached behaviors. 


\section{Shame and Guilt}

Between scholars, there is no agreement about the operationalization of shame and guilt. Although shame and guilt are often used together, some theorists state that they need to be differentiated (Tangney \& Dearing, 2002). According to Tangney and Dearing (2002), feelings of guilt usually refer to a specific situation. People who feel guilty want to repair the situation that made them feel guilty. Guilt can therefore be seen as adaptive behavior. Feelings of shame refer to the whole self and make people want to hide from the situation. A consequence of feeling ashamed is a devaluation of the self, and therefore shame is seen as maladaptive behavior.

Other researchers claim that shame and guilt can both be described as maladaptive behavior, and that a clear distinction is not necessary (Harder, Cutler, \& Rockart, 1992; Harder \& Zalma, 1990). Some studies indeed show high correlations between shame and guilt (Harder, Cutler \& Rockart, 1992; Kugler \& Jones, 1992). Harder, Cutler, and Rockart state that this overlap was to be expected because both emotions can be viewed as internalized negative self-evaluations. The high positive correlations between guilt and maladaptive behavior, like depression en anxiety suggest as well that guilt can be seen as maladaptive behavior (Harder, Cutler, \& Rockart, 1992; Harder \& Zalma, 1990; Jones \& Kugler, 1993; Quiles \& Bybee, 1997).

Since there are different theories about the operationalization of shame and guilt, there are also important differences in tests. This becomes clear in a research of Quiles and Bybee (1997). Quiles and Bybee made a distinction between chronic and predispositional guilt. Where the first one is a continual feeling of guilt (maladaptive), the latter is a feeling of guilt as a consequence of a specific situation (adaptive). In order to compare the results in this research area, it is important to distinguish between the different measures. Quiles and Bybee used both measures and found a positive relation of guilt as a consequence of a specific situation with church attendance and with importance of God. This relationship was not found for continual feelings of guilt. Luyten, Corveleyn, and Fontaine (1998) found second naiveté (symbolic belief) to have a positive relationship with both a continual feeling of guilt and guilt as a consequence of a specific situation. However, the latter relation was stronger than the first. Thus, we can conclude that the relationship of guilt and shame with religion is ambiguous. 


\section{Self-esteem and Self-actualisation}

Another important variable used in the research of religion and mental health is self-esteem. Self-esteem goes together with many other aspects of mental health. Persons with low self-esteem are more likely to appear depressed and more likely to express feelings of unhappiness (Rosenberg, 1965). Although the results concerning the relation of depression (as argued before) and happiness (as will be argued later on) with religion are consistent, this is not the case for selfesteem. Some results pointed in a positive direction (Ryan, Rigby, \& King, 1993), while in some studies no relationship appeared (Blaine, Trivaldi, \& Eshleman, 1998; Commerford \& Reznikoff, 1996). Gartner (1996) concluded as well that the results are mixed.

The results in research concerning religion and self-actualisation do seem to point in one direction. Gartner (1996) reviewed 15 studies in this area and all showed a negative relationship. However, all these studies used the Personal-Orientation Inventory (POI) to measure self-actualisation. In this scale, the items concerning religion (e.g., I am religious orthodox) contribute to a lower score in selfactualisation (Gartner, 1996). It therefore seems that the designers of this scale linked religion to low self-actualisation in advance. Thus, this scale does not seem to be a neutral instrument to measure this relationship. Furthermore, Gartner (1996) noticed that research with the Short Index of Self-Actualization (SISA) found a positive relationship between self-actualization and religion. This relationship was also found in a study by Ryan, Rigby, and King (1993), using the Index of Self-Actualisation (SAI). In sum, previous research seems to indicate that self-actualisation, measured with a neutral scale, relates positively to religion.

\section{Purpose in Life}

Findings in the research of religion and purpose in life have shown a positive relationship (Crandall \& Ramussen, 1975; Peterson \& Roy, 1985; Soderstrom \& Wright, 1977). Paloutzian (1981) found that one week after conversion, the scores on purpose in life had increased greatly. After one month these scores lowered to a level almost comparable with the non-converted group, but six months after conversion, religious persons scored significantly higher than the non-converted group. These results remained stable after six months. 
However, this positive relationship does not hold for orthodox religious persons (Petersen \& Roy, 1985). In a study of Soderstrom and Wright (1977), the committed orientation and consensual orientation were measured. The committed orientation refers to "a religious belief system that is abstract, discerning, well-differentiated, flexible and open, and relevant to one's life" and the consensual orientation refers to "a religious belief system that is concrete and literal, vague, simplistic and undifferentiated, inflexible, and detached from life" (p. 66). The results showed that the committed scored significantly higher on purpose in life than the consensual. There was no significant relationship found between the consensual religious orientation and purpose in life. We can conclude that the relationship of religion with purpose in life needs to be differentiated. Again a literal or symbolic attitude towards religion is of significant importance.

\section{Openness to Experience}

Openness to experience is also an important aspect of mental health. A person who is open will assimilate more new information than a person who is not. Blocking oneself from new information can lead to disconnection or isolation from the real world, which is seen as mentally unhealthy behavior (Batson, Schoenrade, \& Ventis, 1993). In research concerning religion and personality traits however, most researchers have used the Eysencks model, which contains the traits psychoticism, neuroticism and extraversion, but not openness. Apparently, this relationship is not considered important. However, according to McCrae (1999), openness is the most important personality trait in the study of religion and should be included. This point of view is strengthened by the results of Streyffeler and McNally (1998). They compared a group of liberal and fundamental Protestant Christians on the Big Five personality traits and found significant results for openness, while no significant results were found for the other personality traits (neuroticism, agreeableness, conscientiousness and extraversion). Furthermore, fundamentalists scored significantly lower on openness than liberals. Likewise, in the meta-analysis Saroglou (2002) carried out, religious fundamentalism had a negative relationship with openness. Thus there seems to be evidence that a literal attitude towards religion goes together with low openness to experience. 
Subjective Well-being (happiness and life satisfaction)

There has been a great amount of interest in the relationship between religion and well-being, and the evidence that this is a positive relationship can be called substantial (e.g., Witter, Stock, Okun, \& Haring, 1985). However, the concept of subjective well-being is rather broad and can be divided into different components. In a research of Ellison (1991) where a direct influence of religion on well-being was found, well-being was expected to have two dimensions; a cognitive (life satisfaction) and an affective (happiness). We use the same concepts in our study.

A number of studies have shown a positive relationship between religion and happiness (Francis, Robbins, \& White, 2003; French \& Joseph, 1999), but some have failed to find significant results (Lewis, Lanigan, Joseph, \& de Fockert, 1997; Lewis, Maltby, \& Burkinshaw, 2000). There are also some studies that failed to find a relationship between life satisfaction and religion (Lewis, Joseph, \& Noble, 1996; Lewis, Lannigan, Joseph, \& de Fockert, 1997). Nevertheless, a great amount of studies found a positive correlation (Blaine, Trivedi, \& Eshleman, 1998; Chamberlain \& Zika, 1992; Diener \& Clifton, 2002; Diener, Suh, Lucas, \& Smith, 1999). Gartner (1996) affirmed as well a positive relationship.

\section{Hypotheses}

After reviewing the literature on religion and mental health, expectations concerning the results of the present study emerged. Although the literature shows mixed results for some aspects of mental health, there seems to be an overall positive relationship between religion and mental health. Therefore, our first expectation is a positive relationship of all measures of "intrinsic pro-religiousness" (belief salience, intrinsicness and exclusion vs. inclusion of transcendance) with mental health.

However, this relationship needs to be differentiated. As described above, some studies showed that this positive relationship was not present for orthodox persons. The relationship in some cases even pointed into the other direction. This leads us to a second expectation that brings in the aspect of how a person believes. We expect literal vs. symbolic to have a positive correlation with mental health; the 
higher a person scores on symbolic attitude towards religion, the higher we expect the person to score on mental health.

Furthermore, while it seems that the positive aspects of mental health have a clear relation with religion (e.g., happiness, life satisfaction), the relation between the negative aspects and religion are less clear (e.g., shame and guilt). In the present study, we therefore expect the relationship of all measures of intrinsic pro-religiousness with the positive aspects of mental health to be stronger than the relationship with the negative aspects.

Not only do we want to explore the relationship between religion and mental health, our interest also lies in the diversity of measures of religion used in research. Different measures lead to different outcomes and it is therefore important to find out which measures can be used best. As stated before, we lay stress on the PCBS because it measures both if and how a person is religious. We expect both these dimensions to be of importance in the religion-mental health relationship. This brings us to our final hypothesis: we expect the PCBS to have the greatest explained variance of all religious measures used in this study.

\section{Method}

\section{Participants and procedure}

The sample consisted of 130 Dutch adults. Of the participants, 52 identified themselves as male and 74 as female; four persons didn't fill in this question. Their age ranged from 19 to 80 years old, with a mean age of 41.4 years $(\mathrm{SD}=16.3)$. The sample had mostly highly educated subjects $(51 \%)$, and a smaller part had secondary $(43 \%)$ or primary $(1 \%)$ education ( $5 \%$ were missing values). Furthermore, $44 \%$ considered themselves not religious and $52 \%$ considered themselves religious ( $4 \%$ were missing values). Of the participants, $26 \%$ visits the church at least once a month.

Relatives, friends, and acquaintances of the authors were asked to distribute questionnaires to their social contacts (e.g., colleagues and neighbours). We handed out 170 questionnaires; 40 questionnaires were not returned (a response rate of 76.5\%). The participants were told that the study was about 'religion and feelings' and confidentiality and anonymity were guaranteed. 


\section{Measures}

Most of the scales used in our study had no official Dutch translation. Therefore, these scales were translated by two independent translators, using the modified parallel blind technique (Behling \& Law, 2000). When differences in translation appeared, a native English speaker checked the items.

\section{Measures of Religion}

\section{Post-Critical Belief Scale}

(PCBS; Duriez, Fontaine \& Hutsebaut, 2000). The PCBS consists of 33 items on a 7 -point Likert-scale $(1=$ completely disagree, $7=$ completely agree), and is designed to measure whether a person believes or not (the inclusion vs. exclusion of transcendence axis in Wulff's model), and if his or her attitude towards religion is literal or symbolic (the literal vs. symbolic axis in Wulff's model). This leads to four religious attitudes: second naiveté (e.g., 'The bible holds a deeper truth which can only be revealed by personal reflection'), orthodoxy (e.g., 'God had been defined for once and for all and therefore is immutable'), external critique (e.g., 'Faith is more of a dream which turns out to be an illusion when one is confronted with the harshness of life') and relativism (e.g., 'Each statement about God is a result of the time in which it was made'). To see if the two dimensions were also present in our sample, a Principal Component Analysis (PCA) was carried out. A screen test showed two factors and a Procrustes rotation was carried out towards the structure found by Fontaine, Duriez, Luyten, and Hutsebaut (2003). Tucker's Phi indices were above .90 for both components, so the factors can be interpreted as exclusion vs. inclusion of transcendence and literal vs. symbolic. In our study Cronbach's alpha was .82 for second naiveté, 82 for orthodoxy, .86 for external critique and .74 for relativism.

\section{'Age Universal' I-E Scale-12}

(Maltby, 1999). This scale consists of 12 items, that can be answered on a 3-point Likert-scale ( $1=$ yes, $3=$ no). The 'Age Universal' I-E scale-12 is a modified version of the original 'Age Universal' I-E scale (Gorsuch \& Venable, 1983). The 'Age Universal' I-E scale was 
derived from the Religious Orientation Scale (Allport \& Ross, 1967) and developed to measure intrinsic and extrinsic religious orientation in both children and adults. In research by Maltby (1999) with the 'Age Universal' I-E scale, three instead of the original two factors were found. The three factors were interpreted as the intrinsic (religion as a master motive, e.g., 'I try hard to live my life according to my religious beliefs'), extrinsic personal (religion as a source of comfort, relief, and protection, e.g., 'I pray mainly to gain relief and protection') and extrinsic social orientation (religion as a source of social contacts, e.g., 'I go to church because it helps me make friends'). These three factors were also present in our study. We carried out a PCA and a screen test pointed to three factors. The items for intrinsic, extrinsic personal and extrinsic social loaded very high (eigenvalues above .60) on three separate factors and explained $74 \%$ of the variance. Maltby and Day (2000) reported alphas of 0.82, 0.72, and 0.73 for the scales intrinsic, extrinsic personal, and extrinsic social respectively. In the present study, we found alphas of .91, .76, and .84 for intrinsic, extrinsic personal, and extrinsic social, respectively.

\section{Importance of Religion}

Participants were asked to indicate how important belief is to them on a 4 -point Likert scale $(1=$ not important, $4=$ very important).

\section{Church Aattendance}

Participants were asked to rate how often they attend to church on a 5 -point Likert scale ( $1=$ never, $5=$ more than once a week).

\section{Measures of Mental Health}

\section{Center for Epidemiologic Studies Depression Scale}

(CES-D; Radloff, 1977). The CES-D is developed to measure depressive symptomatology in the general population. We used a shortened version of 12 items. The items consist of depression symptoms (e.g., 'I felt depressed' and 'I enjoyed life' [reverse coded]) and respondents were asked how often they have had these experiences during the last week on a 4-point Likert-scale $(1=$ hardly ever or never, $4=$ most of the time or all the time). Research with the CES-D has found that the scale has high internal consistency and acceptable 
test-retest stability (Radloff, 1977). In our study, Cronbach's alpha was .80 .

\section{Anxiety Subscale from the Symptom Checklist-90}

(SCL-90; Arrindell \& Ettema, 1986). The SCL-90 is a multidimensional checklist that covers several clinical fields. The ten items cover different anxiety complaints (e.g., 'trembling' and 'feeling tense') and the participants were asked in what degree they were bothered with these complaints on a 5 -point Likert-scale $(1=$ not at all, $5=$ a lot). Research with the SCL-90 showed an internal consistency between .71 and .91 (Arrindell \& Ettema, 1986). In the present study, Cronbach's alpha was .87.

\section{Weinberger Adjustment Inventory}

(WAI; Weinberger \& Schwartz, 1990). The WAI is designed to measure distress and restraint. Our interest was to measure restraint. Restraint refers to "suppression of egoistic desires in the interest of long-term goals and relations" (Weinberger, 1997, p. 132). We used a shortened version of 12 items on a 5-point Likert-scale $(1=$ completely disagree, $5=$ completely agree). The WAI-restraint consists of four subscales: suppression of aggression (e.g., 'people who get me angry had better watch out' [reverse coded]), impulse control (e.g., 'I do things without giving them much thought' [reverse coded]), consideration of others (e.g., 'I think of other people's feelings before I do something they might not like'), and responsibility ('when I have the chance, I take things that don't really belong to me' [reverse coded]). Weinberger (1997) found alpha coefficients between .85 and .91 for restraint. In the present study we found a Cronbach's alpha of .80 .

\section{Personal Feelings Questionnaire}

(PFQ-2; Harder \& Zalma, 1990). The PFQ-2 contains a 10-item shame subscale and a 6 -item guilt subscale. The respondent was asked to rate how often he or she is aware of the feelings that were listed (e.g., 'embarrassed' and 'feeling ridiculous' as shame items and 'mild guilt' and 'worry about injuring someone' as guilt items) on a 4 -point Likert-scale ( $0=$ never, $4=$ constantly or almost constantly). Harder and Zalma (1990) reported Cronbach's alphas of .78 for the 
shame subscale and .72 for the guilt subscale. Cronbach's alphas in the present study were .77 for the shame subscale and .64 for the guilt subscale.

\section{Rosenberg Self-Esteem Scale}

(RSES; Rosenberg, 1965). This scale was developed to measure global and personal self-evaluations (Rosenberg, 1965). The scale contains 10 items (e.g., 'On the whole, I feel satisfied with myself') and answers can be given on a 4-point Likert-scale $(1=$ strongly agree, $4=$ strongly disagree). According to Rosenberg (1965) the RSES shows high levels of internal consistency. In our study we found a Cronbach's alpha of .86.

\section{Self-Actualization Index}

(SAI; Jones \& Crandall, 1986). This scale consists of 15 items and is designed to measure the degree to which a person is able to fulfil his or her potential (Jones \& Crandall). The items (e.g., 'It is better to be yourself than to be popular') were rated on a 4-point Likertscale $(1=$ completely disagree, $4=$ completely agree). The internal consistency found by Jones and Crandall was .65. In our study we found a Cronbach's alpha of .70.

\section{Purpose in Life Test}

(PIL; Crumbaugh \& Maholick, 1964). This scale consists of 22 items (e.g., 'I am usually completely bored/exuberant, enthusiastic') on a 7-point Likert-scale. Crumbaugh and Maholich found that the reliability of the PIL was .81. In this study Cronbach's alpha was .89.

\section{OPEN subscale from $N E O-F F I$}

(Costa \& McCrae, 1992). The NEO-FFI is a short version of the NEO-PI-R, which is developed to measure the domains of the fivefactor personality model (FFM). These domains are neuroticism, extraversion, openness to experience, agreeableness, and conscientiousness. In this research we only used the Dutch version of subscale openness. This scale consists of 12 items (e.g., 'I often try new and exotic dishes') on a 5 -point Likert-scale $(1=$ completely disagree, 5 $=$ completely agree). Research examining the reliability of this scale reported an alpha of .65 (Caruso, 2000). In our study Cronbach's alpha was .82. 


\section{Satisfaction With Life Scale}

(SWLS; Diener, Emmons, Larson, \& Griffin, 1985). The SWLS is developed to obtain a person's cognitive judgement about his or her life. The test consists of 5 items (e.g., 'the conditions of my life are excellent') that can be answered on a 7 -point Likert-scale ( $1=$ completely disagree, $7=$ completely agree). Diener et al. (1985) reported an alpha coefficient of .87. In our study Cronbach's alpha was .82.

\section{Oxford Happiness Questionnaire}

(OHQ; Hills \& Argyle, 2002). The Oxford Happiness Questionnaire is a shortened version of the Oxford Happiness Inventory $(\mathrm{OHI}$; Argyle, Martin, \& Crossland, 1989). The original number of 29 items was reduced to 8 items (e.g., 'I find beauty in some things') and the items can be answered on a 6-point Likert scale $(1=$ completely disagree, $6=$ completely agree). Hills and Argyle (2002) found an alpha of .91 for the OHQ. In our study Cronbach's alpha was .61.

\section{Results}

Pearson correlations were conducted between all religious measures and mental health variables. We found several significant correlations (Table 1). Belief salience relates positively to six aspects of mental health: self-esteem, self-actualisation, purpose in life, happiness, life satisfaction, and restraint. Church attendance also relates to different aspects of mental health: it goes together with lower levels of anxiety and higher levels of purpose in life. The results of the Age Universal I-E scale-12 show that extrinsic social is unrelated to the mental health measures. Extrinsic personal only relates positively to guilt. The intrinsic measure, however, relates to six aspects of mental health: depression, self-actualisation, purpose in life, happiness, life satisfaction and restraint. Concerning the two dimensions of the PCBS, we found inclusion of transcendence to relate to higher levels of purpose in life and restraint and to lower levels of openness. Symbolic thinking related to lower levels of depression and higher levels of self-esteem, purpose in life, happiness and openness.

We have earlier mentioned the importance of distinguishing mental health as positive mental health and negative mental health when examining its relationship with religion. Therefore, the positive mental health variables (self-esteem, self-actualisation, purpose in life, happiness, 
Table 1 Correlations between religious measures and measures of mental health

Religious measures

\begin{tabular}{|c|c|c|c|c|c|c|c|}
\hline $\begin{array}{l}\text { Measures of } \\
\text { mental health }\end{array}$ & $\begin{array}{c}\text { Belief } \\
\text { salience }\end{array}$ & $\begin{array}{c}\text { Church } \\
\text { attendance }\end{array}$ & Intrinsic & $\begin{array}{c}\text { Extrinsic } \\
\text { social }\end{array}$ & $\begin{array}{l}\text { Extrinsic } \\
\text { personal }\end{array}$ & $\begin{array}{l}\text { Inclusion vs. } \\
\text { exclusion }\end{array}$ & $\begin{array}{l}\text { Literal vs. } \\
\text { symbolic }\end{array}$ \\
\hline Depression & -.15 & -.14 & $-.21 *$ & .06 & .00 & -.17 & $-.22 *$ \\
\hline Anxiety & -.17 & $-.18 *$ & -.14 & -.04 & -.07 & -.17 & -.05 \\
\hline Guilt & -.07 & -.01 & .00 & -.01 & $.19^{*}$ & .10 & -.05 \\
\hline Shame & -.13 & -.06 & -.05 & -.11 & .06 & -.02 & -.02 \\
\hline Self-esteem & $.22 *$ & .04 & .12 & -.08 & -.06 & .01 & $.19 *$ \\
\hline Self-actualisation & $.25^{* *}$ & .10 & $.20 *$ & -.04 & -.05 & .11 & .18 \\
\hline Purpose in life & $.33^{* *}$ & $.19 *$ & $.27 * *$ & -.03 & .11 & $.24^{*}$ & $.21^{*}$ \\
\hline Happiness & $.25^{* *}$ & .09 & .20 & .04 & -.02 & .10 & $.31 * *$ \\
\hline Life satisfaction & $.23^{*}$ & .16 & $.18 *$ & .02 & -.03 & .17 & .01 \\
\hline Openness & -.01 & -.16 & .05 & -.07 & -.16 & $-.18 *$ & $.30 * *$ \\
\hline Restraint & $.22^{*}$ & .14 & $.21^{*}$ & .01 & .12 & $.22^{*}$ & .05 \\
\hline Positive $\mathrm{mh}$ & $.33^{*}$ & .13 & $.28 *$ & -.04 & -.02 & .15 & $.28 * *$ \\
\hline Negative $\mathrm{mh}$ & -.18 & -.13 & -.14 & -.04 & .06 & -.09 & -.11 \\
\hline
\end{tabular}

$* \mathrm{p}<.05 . * * \mathrm{p}<.01$

life satisfaction, openness and restraint) were standardised and combined to one variable (POSMH), and the same procedure was executed for negative mental health (NEGMH) with the variables depression, anxiety, guilt and shame. The correlations show that belief salience, intrinsicness and symbolic belief relate to higher levels of positive mental health. None of the religious measures relate to negative mental health. These results are in agreement with our expectations.

The aim of the next analyses was to investigate which religious measure has the highest predictive power. To explore this, we measured the explained variance of the single items belief salience and church attendance, the 'Age Universal' I-E Scale-12, and the PCBS for both positive and negative mental health. Belief salience, the 'Age Universal' I-E Scale-12, and the PCBS were all found significant predictors for positive mental health $(\mathrm{F}(1,123)=15.51, \mathrm{p}<.000$; $\mathrm{F}(3,125)=6.00, \mathrm{p}<.001 ; \mathrm{F}(2,123)=8.38, \mathrm{p}<.000)$. This was not the case for church attendance $(\mathrm{F}(1,123)=1.99, \mathrm{p}=.160)$. In disagreement with our expectations, table 2 shows that the 'Age Universal' I-E Scale-12 explains the largest amount of variance for positive mental health. However the differences with the PCBS and 
Table 2 Explained variances of the measures of religion for positive and negative mental health

Measures of religion

\begin{tabular}{llccl}
\hline $\begin{array}{l}\text { Measures of } \\
\text { mental health }\end{array}$ & $\begin{array}{c}\text { Belief } \\
\text { salience }\end{array}$ & $\begin{array}{c}\text { Church } \\
\text { attendance }\end{array}$ & $\begin{array}{c}\text { 'Age universal' } \\
\text { I-E scale-12 }\end{array}$ & PGBS \\
Positive $\mathrm{mh}$ & $\mathrm{R}^{2}=.11^{*}$ & $\mathrm{R}^{2}=.02$ & $\mathrm{R}^{2}=.13^{*}$ & $\mathrm{R}^{2}=.12^{*}$ \\
Negative $\mathrm{mh}$ & $\mathrm{R}^{2}=.03$ & $\mathrm{R}^{2}=.02$ & $\mathrm{R}^{2}=.05$ & $\mathrm{R}^{2}=.03$ \\
\hline
\end{tabular}

$* \mathrm{p}<.001$

belief salience are small. Only church attendance explains almost no variance of positive mental health.

For negative mental health, none of the regressions with belief salience, church attendance, the 'Age Universal' I-E Scale-12, and the PCBS were significant $(\mathrm{F}(1,124)=3.52, \mathrm{p}=.063 ; \mathrm{F}(1,124)=1.99$, $\mathrm{p}=.161 ; \mathrm{F}(3,126)=2.31, \mathrm{p}=.080 ; \mathrm{F}(2,124)=1.86, \mathrm{p}=.161)$.

Furthermore, we executed three regressions with belief salience, the three factors of the 'Age Universal' I-E Scale-12, and the two dimensions of the PCBS as predictors for positive mental health in model 1 , and the control variables age, sex, and education in model 2. The results are shown in table 3 . Belief salience is a significant predictor for positive mental health in the first as well as in the second model $(\mathrm{F}(1,110)=19.65, \mathrm{p}<.000 ; \mathrm{F}(4,107)=7.79, \mathrm{p}<$ $.000)$. Also, education is found to be a significant predictor of positive mental health. The factors of the 'Age Universal' I-E Scale-12 were also significant predictors in both models $(\mathrm{F}(3,108)=5.26$, $\mathrm{p}<.01 ; \mathrm{F}(6,105)=3.96, \mathrm{p}<.001)$. However, as table 3 shows, only the factor intrinsic is significant. Of the control variables that are included in the second model, education is again a significant predictor of mental health. When examining the regression with the dimensions of the PCBS, again both models are significant $(\mathrm{F}(2,106)$ $=7.00, \mathrm{p}<.001 ; \mathrm{F}(5,103)=3.88, \mathrm{p}<.01)$. The first model shows that both dimension are predictors. In the second model literal vs. symbolic looses its significance and exclusion vs. inclusions is still significant. Similar to the regressions we discussed previously, education is also here a significant predictor.

The importance of education as a significant predictor of mental health could be explained by relationship between the religiosity 
Table 3 Regression analyses on positive mental health

Model 1

Religion single item

Belief salience

Control variables

Age

Sex

Education

$\mathrm{R}^{2}$

Adjusted $\mathrm{R}^{2}$

\section{Model 2}

$.36 * *$

.12

.06

$.28 * *$

.23

.20

\section{Model 1}

Model 2

\section{Religion I-E scale}

Intrinsic

$\begin{array}{ll}.44 * * & .45 * * \\ -.23 * & -.19 \\ -.01 & -.08\end{array}$

Extrinsic personal

Extrinsic social

$-.01$

$-.08$

\section{Control variables}

Age

Sex

.07

Education

$\mathrm{R}^{2}$

Adjusted $\mathrm{R}^{2}$

$\begin{array}{ll} & .15 \\ & .07 \\ & .24 * * \\ .13 & .18 \\ .11 & .14\end{array}$

Model 1

Model 2

\section{Religion PCBS}

Exclusion vs. inclusion

Literal vs. symbolic

$\begin{array}{ll}.18^{*} & .21 * \\ .30^{* *} & .16\end{array}$

Control variables

Age

.14

Sex

.05

Education

$\mathrm{R}^{2}$

Adjusted $\mathrm{R}^{2}$

Note: cell entries are standardised coefficients $* \mathrm{p}<.05 . * * \mathrm{p}<.01$.

measures and education. Therefore, correlations of the sociodemographic variables and the religious measures are added in table 4 . Only the relation between education and symbolic vs. literal is significant. None of the others show a significant relation, indicating that education is indeed a significant predictor of mental health. 
Table 4 The correlations between the socio demographic and the religious variables

\section{Religious variables}

Socio- Belief Intrinsic Extrinsic Extrinsic Inclusion vs. Literal vs. demographicsalience social personal exclusion symbolic

\begin{tabular}{lcrrrrr}
\hline Sex & .04 & .06 & -.08 & .11 & .17 & -.10 \\
Age & $.21^{*}$ & .17 & .02 & .14 & .15 & -.06 \\
Education & -.02 & .09 & -.03 & -.15 & -.08 & $.48^{* *}$ \\
\hline
\end{tabular}

$* \mathrm{p}<.05 . * * \mathrm{p}<.01$.

So far, it appears that belief salience, the 'Age Universal' I-E Scale12 , and the PCBS are all significant predictors for positive mental health. Nonetheless, the difference between these measures of religiosity lies in the disctinction of the PCBS in if and how a person is religious. Therefore, to obtain a clear view of the religion-mental health relation, figure 1 presents a correlation matrix with the two dimensions of the PCBS used as axis. When examining the positions of the mental health variables, we notice a clear pattern; all the aspects of positive mental health, except for openness, lie in the second naiveté quadrant (inclusion and symbolic) and all the aspects of negative mental health, except for guilt lie in the external critique quadrant (exclusion and literal).

\section{Discussion}

As stated in the introduction, researchers have gathered evidence for the existence of a positive relationship between religion and mental health. In the present study, the results also point in this direction. All measures of religious commitment (belief salience, intrinsicness, and exclusion vs. inclusion of transcendence) are positively related to multiple aspects of mental health.

Church attendance, extrinsic social and extrinsic personal however, were hardly related to any aspect of mental health. This result was not surprising since, as argued before, it is questionable if these variables are eligible to explain the relationship between religion and mental health, more than others. Church attendance was used here as a religious measure. However, although $44 \%$ of the participants in the present study identified themselves as being religious, only $26 \%$ visit a church at least once a month. Therefore, church attendance 
Figure 1 Correlationmatrix with the two dimensions of the PCBS (on the axis) and mental health variables

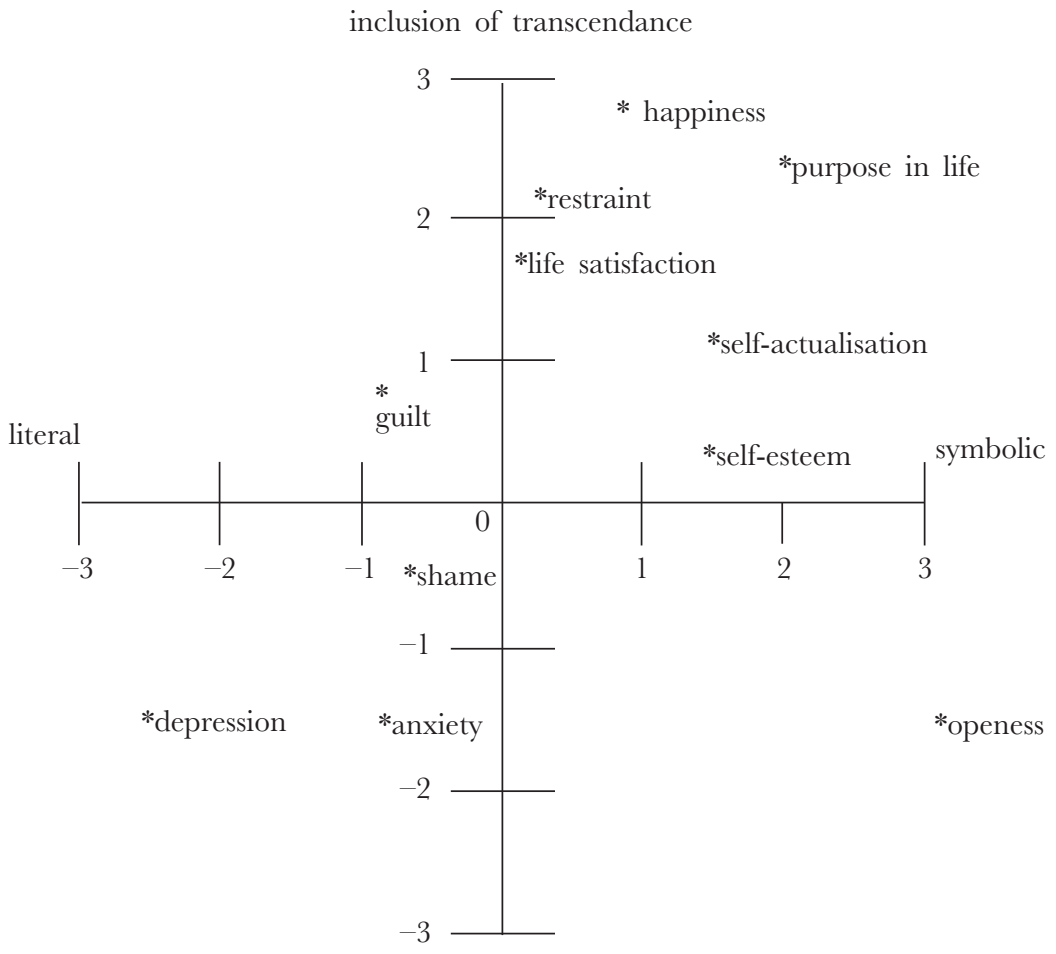

exclusion of transcendance

Note: not all correlations are significant

does not have enough overlap with religion to qualify as a measure of religious commitment. Extrinsic personal and extrinsic social can neither be seen as measures of religious commitment. In spite of this, researchers still use these three measures nowadays. In the present study, church attendance, extrinsic personal, and extrinsic social proved unrelated to most aspects of mental health. However, if researchers are unaware of the relatively low overlap between these measures and religious commitment, their use can lead them to belief that no relationship between religion and mental health exists. It therefore seems recommendable to use better measures of religious commitment, for example belief salience and intrinsicness. In the 
present study, belief salience and intrinsicness relate significantly to mental health, which provides evidence for the existence of a positive relationship between religion and mental health. However, this relationship needs to be refined. Although belief salience and intrinsicness give a good representation of if a person is religious, they do not differentiate between how a person is religious. This differentiation is of significant importance, which becomes clear in our results with the PCBS. Correlations show that interpreting religion in a symbolic way also is related to multiple aspects of mental health. When putting these correlations in a matrix we see a clear pattern. The symbolic believers score the highest on positive mental health and the literal unbelievers score the highest on negative mental health. Thus, amoung our Dutch participants it appears that persons who are religious only benefit from better mental health when they believe in a symbolic way. This conclusion corresponds to an earlier notice that a positive religion-mental health relationship is often not found with orthodox persons.

Second, our results also show that a differentiation needs to be made for mental health. The positive aspects of mental health (well-being) and the negative aspects (psychological distress) are differently related to religion, which has also been stated by other researchers (Ellison, Boardman, Williams, \& Jackson, 2001). The first relate mainly positively to religion, whereas the latter are more ambiguously related. In our study, the exclusion vs. inclusion and the literal vs. symbolic dimensions both showed a positive relationship with positive mental health. No relationship with negative mental health emerged. This strengthens the view that the positive relationship with religion especially concerns positive mental health. Nevertheless, we should be careful in stating that no relationship with negative mental health exists. Most measures of psychological distress show no clear relationship, but research concerning religion and depression usually does find a negative relationship. The results in our study also show a negative relationship of second naiveté and intrinsicness with depression. An explanation for this relation could be that depression is rather an inverse measure of well-being than that it is a measure of psychological distress. Some researchers have already argued that depression and happiness are opposites and lie on one bipolar axis (Joseph \& McCollam, 1993). Therefore, it is first of all necessary to get a clear picture of what negative mental health exactly is. Only 
then we are able to obtain a better understanding of the underlying aspects of the relation or the absence of a relation between religion and negative mental health.

Although the importance of distinguishing between if and how you believe comes clear in this study, our hypothesis that stated that the PCBS should explain the largest amount of variance in predicting mental health was not confirmed. Regression analyses showed that the single item belief salience, the 'Age Universal' I-E Scale-12, and the PCBS are all three predictors of positive mental health, and all explained approximately the same amount of variance. Moreover, after checking for the sociodemographic variables sex, age and education, it appears that education accounts for a significant contribution to positive mental health. After adding education as preditor for positive mental health, the explained variance increased in all models, but in particular in the model with belief salience. Thus, contrary to our expectation, belief salience together with education explain the largest amount of variance in predicting positive mental heatlh.

Although our study has revealed some important results, we should also notice its limitations. Our sample was rather small, and homogenous concerning education level. It largely consisted of highly educated persons. This makes the generalizability of the findings questionable. Further research should point out whether these results also emerge in a sample that better represents the Dutch population. Furthermore, it should be noticed that the correlations and explained variances are rather low. Obviously, both religiosity as mental health are highly complex concepts, which fully understanding demands more research.

In this research we illuminated several aspects of both religion and mental health that are related to each other. Of course, not all aspects that have a role in this relationship were examined. Now we found that believers are more well than non-believers, we wonder what it is that makes them happier or more satisfied with their lives. And how important is education and purpose in life in this relationship? In further research, these relationships need to be examined further so it can be expanded. 


\section{References}

Allport, G.W., \& Ross, J.M. (1967). Personal religious orientation and prejudice. Fournal of Personality and Social Psychology, 5 (4), 432-433.

Arrindell, W.A., \& Ettema, J.H.M. (1986). Klachtenlijst (SCL-90). The Netherlands, Lisse: Swets \& Zeitlinger.

Batson, C.D., Schoenrade, P.A., \& Ventis, W.L. (1993). Religion and the individual: A social psychological perspective. London: Oxford University Press.

- (1993). Mental health or sickness? In N.N. (Ed.), Religion and the Individual: A social psychological perspective (pp. 230-291). London: Oxford University Press.

Beck, S.H., Cole, B.S., \& Hammond, J.A. (1991). Religious heritage and perimarital sex: Evidence from a national sample of young adults. Fournal for the Scientific Study of Religion, 30, 173-180.

Behling, O., \& Law, K.S. (2000). Translating questionnaires and other research instruments: Problems and solutions. Sage University Papers Series on Quantitative Applications in the Social Sciences, 133 (7). Thousand Oaks, CA: Sage.

Bergin, A.E., Masters, K.S., \& Richards, P.S. (1987). Religiousness and mental health reconsidered: A study of an intrinsically religious sample. fournal of Counseling Psychology, 34 (2), 197-204.

Blaine, B.E., Trivedi, P., \& Eshleman, A. (1998). Religious belief and the self-concept: Evaluating the implications for psychological adjustment. Personality and Social Psychology Bulletin, 24 (10), 1040-1052.

Braam, A.W., Beekman, A.T.F., Deeg, D.J.H., Smit, J.H., \& van Tilburg, W. (1997). Religiosity as a protective or prognostic factor of depression in later life: Results from a community survey in the Netherlands. Acta Psychiatrica Scandinavia, 96 (3), 199-205.

- (1994). Religiositeit en depressieve symptomen bij ouderen. Tijdschrift voor Psychiatrie, 36 (7), 509-519.

Caruso, J.C. (2000). Reliability generalization of the NEO personality scales. Educational and Psychological Measurement, 60, 236-254.

CBS (2002). Kerkelijkheid in Nederland. http://wrewe.cbs.nl/nl/publicaties/artikelen/algemeen/ webmagazine/ artikelen/2002/1094k.html. Posted: 12/23/02. Visited: 05/21/04.

Chamberlain, K., \& Zika, S. (1992). Religiosity, meaning in life, and psychological well-being. In J.F. Schumaker (Ed.), Religion and mental health (pp. 138-148). New York: Oxford University Press.

Cochran, J.K., \& Beeghley, L. (1991). The influence of religion on attitudes toward nonmarital sexuality: A preliminary assessment of reference group theory. Fournal for the Scientific Study of Religion, 30, 45-62.

Commerford, M.C., \& Reznikoff, M. (1996). Relationship of religion and percieved social support to self-esteem and depression in nursing home residents. Fournal of Psychology, 130 (1), 35-50.

Costa, P.T.Jr., \& McCrae, R.R. (1992). Revised NEO Personality Inventory (NEOPI-R) and the Five Factor Inventory (NEO-FFI): Professional manual. Odessa, Florida: Psychological Assessment Resources Inc.

Crandall, V.C., \& Ramussen, R.D. (1975). Purpose in life as related to specific values. Fournal of Clinical Psychology, 31, 483-485.

Crumbaugh, J.C., \& Maholick, L.T. (1964). An experimental study in existentialism: The psychometric approach to Frankl's concept of noogenic neurosis. Fournal of Clinical Psychology, 2, 200-207.

Diener, E. (2001). Satisfaction with life scale. http://www.psych.uiuc.edu/ ediener/ hottopic/hottopic.html. Posted: 04/26/01. Visited: 12/22/03.

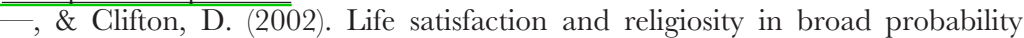
samples. Psychological Inquiry, 13 (3), 206-209. 
S., Emmons, R.A., Larsen, R.J., \& Griffin, S. (1985). The satisfaction with life scale. Foumal of Personality Assessment, 49, 71-75.

, Suh, E.M., Lucas, R.E., \& Smith, H.L. (1999). Subjective well-being: three decades of progress. Psychological Bulletin, 125 (2), 276-302.

Donahue, M.J. (1985). Intrinsic and extrinsic religiousness: Review and meta-analysis. Fournal of Personality and Social Psychology, 48, 400-419.

Dudley, K.L., Mutch, P.B., \& Ciruise, K.J. (1987). Keligious factors and drugs usage among seventh-day adventist youth in North America. Fournal for the Scientific Study of Religion, 26 (2), 218-233.

Duriez, B., Fontaine, J.R.J., \& Hutsebaut, D. (2000). A further elaboration of the Post-Critical Belief Scale: Evidence for the existence of four different approaches to religion in Flanders-Belgium. Psychologica Belgica, 40 (3), 153-181.

Ellison, C.G. (1991). Religious involvement and subjective well-being. Fournal of Health and Social Behavior, 32 (1), 80-99.

-, Boardman, J.D., Williams, D.R., \& Jackson, J.S. (2001). Religious involvement, stress, and mental health: Findings from the 1995 Detroit Area Study. Social Forces, 80 (1), 215-249.

Engs, R.C., \& Mullen, K. (1999). The effect of religion and religiosity on drug use among a selected sample of post secondary students in Scotland. Addictional Research, 7 (2), 149-170.

Feagin, J.R. (1964). Prejudice and relegious types: A focused study of Southern fundamentalists. Fournal for the Scientific Study of Religion, 4 (1), 3-13.

Fontaine, J.R.J., Duriez, B., Luyten, P., \& Hutsebaut, D. (2003). The internal structure of the Post-Critical Belief Scale. Personality and Individual Differences, 35 (3), 501-518.

Francis, L.J., Robbins, M., \& White, A. (2003). Correlation between religion and happiness: A replication. Psychological Reports, 92 (1), 51-52.

French, S., \& Joseph, S. (1999). Religiosity and its association with happiness, purpose in life, and self-actualisation. Mental Health, Religion $\&^{\circ}$ Culture, 2 (2), 117-120.

Frenz, A.W., \& Carey, M.P. (1989). Religiousness and trait anxiety: Factorartifarct. Psychological Reports, 65, 827-834.

Gartner, J. (1996). Religious commitment, mental health, and prosocial behavior: A review of the empirical literature. In E.P. Shafranske (Ed.), Religion and the clinical practice of psychology (pp. 187-214).

Gorsuch, R.L. \& McFarland, S.G. (1972). Single vs. multiple-item scales for measuring religious values. Fournal for the Scientific Study of Religion, 11 (1), 53-64. , \& Venable, G.D. (1983). Development of an "Age Universal" 1-E Scale. Journal for the Scientific Study of Religion, 22 (2), 181-187.

Grasmick, H.G., Kinsey, K., \& Ciochran, J.K. (1991). Denomination, religiosity and compliance with the law: A study of adults. Fournal for the Scientific Study of Religion, 30, 99-107.

Hackney, C.H., \& Sanders, G.S. (2003). Religiosity and mental health: A metaanalysis of recent studies. Fournal for the Scientific Study of Religion, 42 (1), 43-55.

Hadaway, C.K., Elifson, K.W., \& Petersen, D.M. (1984). Religious involvement and drug use among urban adolescents. Fournal for the Scientific Study of Religion, 23 (2), $109-128$.

Haerich, P. (1992). Premarital sexual permissiveness and religious orientation: A preliminary investigation. Fournal for the Scientific Study of Religion, 31 (3), 161-165.

Harder, D.H., \& Zalma, A. (1990). Two promising shame and guilt scales: A construct validity comparison. Fournal of Personality Assessment, 55 (3), 729-745.

, Cutler, L., \& Rockart, L. (1992). Assessment of shame and guilt and their relationships to psychopathology. Fournal of Personality Assessment, 59 (3), 584-604.

Hills, P., \& Argyle, M. (2002). The Oxford Happiness Questionnaire: A compact 
scale for the measurement of psychological well-being. Personality and Individual Differences, 33, 1073-1082.

Hood, R.W.Jr., Spilka, B., Hunsberger, B., \& Gorsuch, R. (1996). The psychology of religion: An empirical approach. New York: Guilford Press.

Hunt, R.A., \& King, M. (1971). Intrinsic-extrinsic concept: Review and evaluation. Fournal for the Scientific Study of Religion, 10 (4), 339-356.

Jones, A., \& Cirandall, R. (1986). Validation of a short index of self-actualization. Personality and Social Psychology Bulletin, 12 (1), 63-73.

Jones, W.H., \& Kugler, K. (1993). Interpersonal correlates of the guilt inventory. Fournal of Personality Assessment, 61, 246-258.

Joseph, S., \& McCillam, P. (1993). A bipolar happiness and depression scale. The fournal of Genetic Psychology, 154 (1), 127-129.

Kirkpatrıck, L.A., \& Hood, R.W.Jr. (1990). Intrınsic-Extrinsic religious orientation: The boon or bane of contemporary psychology of religion. Fournal for the Scientific Study of Religion, 29 (4), 442-462.

Koenig, H.G. (1994). Aging and God: Spiritual pathways to mental health in midlife and later years. New York: Haworth Press.

(1994). Religion and anxiety. In Koenig, H.G. (Ed.), Aging and God: Spiritual pathways to mental health in midlife and later years (pp. 247-279). New York: Haworth Press.

Kugler, K., \& Jones, W.H. (1992). On conceptualizing and assessing guilt. fournal of Personality and Social Psychology, 62 (2), 318-327.

Lewis, C.A., Joseph, S., \& Noble, K.E. (1996). Is religiosity associated with life satisfaction? Psychological Reports, 79, 429-430.

, Lanigan, C., Joseph, S., \& de Fockert, J. (1997). Religiosity and happiness: No evidence for an association among undergraduates. Personality and Individual Differences, 22 (1), 119-121.

- Maltby, J., \& Burkinshaw, S. (2000). Religion and happiness: Still no association. Journal of Beliefs \& Values, 21 (2), 233-236.

Luyten, P., Corveleyn, J., \& Fontaine, J.R.j. (1998). The relationship between religiosity and mental health: Distinguishing between shame and guilt. Mental Health, Religion \& Culture, 1 (2), 165-184.

Maltby, J. (1999). The internal structure of a derived, revised, and amended measure of the religious orientation scale: The 'age-universal' I-E scale-12. Social Behavior and Personality, 27 (4), 407-412.

, \& Day, L. (2000). Examining the relationship between religiosity and depression within the context of other correlates of depression. Personality and Individual Differences, 28, 383-393.

-Lewis, C.A., \& Day, L. (1999). Religious orientation and psychological wellbeing: The role of the frequency of personal prayer. British Fournal of Health Psychology, 4, 363-378.

McCrae, R.R. (1999). Mainstream personality psychology and the study of religion. Fournal of Personality, 67, 1208-1218.

Paloutzian, R.F. (1981). Purpose in life and value changes following conversion. Fournal of Personality and Social Psychology, 41 (6), 1153-1160.

Petersen, L.R., \& Roy, A. (1985). Religiosity, anxiety, and meaning and purpose: Religion's consequences for psychological well-being. Review of Religious Research, $27,49-62$.

Quiles, Z.N., \& Bybee, J. (1997). Chronic and predispositional guilt: relations to mental health, prosocial behavior, and religiosity. Fournal of Personality Assessment, 69 (1), 104-126.

Radloff, L.S. (1977). The CES-D Scale: A self-report depression scale for research in the general population. Applied Psychological Measurement, 1 (3), 385-401. 
Rosenberg, M. (1965). Society and the adolescent self-image. Princeton, NJ: Princeton University Press.

Ryan, R.M., Rigby, S., \& King, K. (1993). Two types of religious internalization and their relations to religious orientations and mental health. Foumal of Personality and Social Psychology, 65 (3), 586-596.

Saroglou, V. (2002). Religion and the five factors of personality: A meta-analytic review. Personality and Individual Differences, 32, 15-25.

Schumaker, J.F. (1992). Religion and mental health. New York: Oxford University Press.

Soderstrom, D. \& Wright, E.W. (1977). Religious orientation and meaning in life. Foumal of Clinical Psychology, 33, 65-68.

Streyffeler, L.L. \& McNally, R.J. (1998). Fundamentalists and liberals: Personality characteristics of prostestant christians. Personality and Individual Differences, 24 (4), 579-580.

Tangney, J.P., \& Dearing, R.L. (2002). Shame and guilt. New York: Guilford Press. Watson, P.J., Morris, R.J., \& Hood, R.W. Jr. (1988). Sin and self-functioning, part 2: Grace, guilt and psychological adjustment. Fournal of Psychology and Theology, $16(3), 270-281$.

Weinberger, D.A. (1997). Distress and self-restraint as measures of adjustment across the life span: Confirmatory factor analyses in clinical and nonclinical samples. Psychological Assessment, 9 (2), 132-135.

, \& Schwartz, G.E. (1990). Distress and restraint as superordinate dimensions of self-reported adjustment: A typological perspective. Foumal of Personality, 58 (2), 381-417.

Welch, H.R., Tittle, C.R., \& Petee, T. (1991). Religion and deviance among adult catholics: A test of the 'moral communities' hypothesis. Fournal for the Scientific Study of Religion, 30 (2), 159-171.

Witter, R.A., Stock, W.A., Okun, M.A., \& Haring, M.J. (1985). Religion and subjective well-being: A quantitative synthesis. Review of Religious Research, 26 (4), 332-342.

Wulff, D.M. 1991). Psychology of religion: Classic and contemporary views. New York: John Wiley \& Sons. 